\title{
Zastosowanie ArcNEO do oceny przejawów neotektoniki na przykładzie zlewni górnego Wieprza (Roztocze, środkowo-wschodnia Polska)
}

\author{
Application of ArcNEO for assessment of neotectonic activity illustrated by the upper \\ Wieprz catchment (Roztocze, south-eastern Poland)
}

\author{
Łukasz Chabudziński, Teresa Brzezińska-Wójcik \\ Wydział Nauk o Ziemi i Gospodarki Przestrzennej, Uniwersytet Marii Curie-Skłodowskiej, Lublin, lchabudzinski@gmail.com
}

\begin{abstract}
Zarys treści: $\mathrm{W}$ opracowaniu zaprezentowano schemat działania narzędzia ArcNEO, zwiększającego funkcjonalność programu ArcGIS 10.1 i pozwalającego na typowanie obszarów względnie mobilnych tektonicznie. Narzędzie ArcNEO działa w oparciu o dane wektorowe (granice zlewni poszczególnych rzędów, wybrane profile poprzeczne zlewni, dla których wyznacza się wartości wskaźnika $V f$, szerokość dna doliny) oraz cyfrowy model wysokościowy (CMW). Generuje ono parametry zlewni oraz trzy grupy wskaźników: dwie (wysokościowe i powierzchniowe) opisujące parametry zlewni oraz jedną (liniową) - opisującą cechy form rzeźby w zlewniach. Wielkości wskaźników są podstawą do oszacowania młodej mobilności tektonicznej. Działanie narzędzia ArcNEO przedstawiono na przykładzie zlewni górnego Wieprza, położonej na lubelskim obszarze wyżynnym. Opracowana aplikacja może być stosowana do wskazywania obszarów względnie aktywnych/nieaktywnych tektonicznie w innych regionach o stosunkowo jednorodnej budowie geologicznej, a także do określania charakterystyk fizjograficznych zlewni.
\end{abstract}

Słowa kluczowe: ArcNEO, ArcGIS, neotektonika, zlewnia górnego Wieprza, Roztocze

Abstract: The current study presents the function of the ArcNEO tool, which increases the functionality of the ArcGIS 10.1 software and facilitates identification of relatively mobile tectonic areas. The ArcNEO tool works on vector layers (boundaries between catchments of different orders, selected transverse catchment profiles with their calculated $V f$ index values, the width of the valley floor) and the digital elevation model (DEM). The tool generates catchment parameters and three groups of indices: two (elevation and surface) describe catchment parameters and one (linear) describes the characteristics of catchment relief. The values of the indices are used in estimation of new tectonic mobility. The function of the ArcNEO tool is presented on the example of the upper Wieprz catchment located in the Lublin Upland area. The application developed can be used to identify relatively active/inactive tectonic areas in other regions characterised by a relatively homogeneous geological structure and to provide physiographic features of catchments.

Key words: ArcNEO, ArcGIS, neotectonics, upper Wieprz catchment, Roztocze

\section{Wstęp}

Zakres opracowań morfometrycznych, opartych na kartometrii, jest stosunkowo szeroki i obejmuje charakterystyki form rzeźby oraz różne wskaźniki absolutne i względ- ne (m.in. Strahler 1952, Birot 1955, Clarke 1966, Pike 1995, Luo 1998, Snyder i in. 2000, Wilson, Gallant 2000, Evans 2004, Grohmann 2004). Wiele opracowań podejmuje próbę podsumowania osiągnięć morfometrii w literaturze światowej (Evans 1972, 2004, Grohmann 2004, 
Pike i in. 2008) oraz polskiej (m.in. Zaborski 1931/1932, Strada 1931/1932, Malicki 1955, Szumowski 1967, Żyszkowska 1978, Dobija 1979).

Współczynniki morfometryczne, charakteryzujące zlewnie, dość dobrze ilustrują zależność systemu rzecznego od skali pionowych ruchów wypiętrzających, określanych mianem neotektoniki (Zuchiewicz 2010). Przejawy młodej aktywności tektonicznej wyrażają się w cechach form rzeźby, opisywanych m.in. przez parametry oraz wskaźniki morfometryczne, np. w zlewniach, oraz ujawniają przestrzenne rozmieszczenie starszych stref tektonicznych na danym obszarze. Na podstawie uzyskanych wartości można oszacować zróżnicowanie dynamiczne w obrębie dość jednorodnego geologicznie systemu (Golts, Rosenthal 1993, Keller, Pinter 2002, Codilean i in. 2006, Wobus $i$ in. 2006, Grohmann i in. 2007, Ascione i in. 2008, Garrote i in. 2008, Khavari i in. 2009, Mumipour, Nejad 2011, Shahzad, Gloaguen 2011a).

Do wskazywania terenów, na których ujawnia się młoda mobilność tektoniczna, na lubelskim obszarze wyżynnym, stosowano początkowo wskaźniki powierzchniowe, określające geometryczne parametry zlewni - maksymalną długość $L$, powierzchnię $A$, oraz wskaźnik wydłużenia $R_{e}$. Ponadto wykorzystano wskaźniki liniowe - krętości krawędzi Smf i szerokości dna-wysokości zboczy Vf, głównie na Roztoczu (m.in. Brzezińska-Wójcik 2013 i literatura tam cytowana) oraz w południowo-zachodniej części Wyżyny Lubelskiej (Warowna 1993). W opracowaniach sprzed 2010 r. wskaźniki te obliczano z map topograficznych w skali 1:10 000 w układzie 1965, używając mechanicznego planimetru biegunowego oraz kalkulatora.

Obecnie narzędzia systemów informacji geograficznej (GIS) stają się coraz bardziej popularne w badaniach nad przejawami względnie młodej aktywności tektonicznej. Powszechny dostęp do baz danych oraz ich dokładność, która cały czas wzrasta, zachęca coraz większe grono badaczy do prowadzenia badań z wykorzystaniem systemów informacji geograficznej i rozwijania nowych metod i narzędzi badawczych w oparciu o jego funkcjonalność (Miliaresis 2001, Bolca i in. 2005). W badaniach nad neotektoniką coraz częściej korzysta się z komercyjnych oraz ogólnie dostępnych aplikacji, które tworzone/rozwijane są jako oddzielne programy lub dedykowane narzędzia/rozszerzenia, zwiększające funkcjonalność już istniejących (Pérez-Peña i in. 2009, Shahzad, Gloaguen 2011a, b). Taki kierunek wskazuje na potrzebę tworzenia nowych narzędzi GIS, które pozwalałyby na powtarzalność i stosowanie metod badań nad młodą aktywnością tektoniczną w różnych regionach świata. Oczekuje się, że nowe narzędzia przyczynią się do zwiększenia obiektywizmu, przyśpieszenia oraz automatyzacji metod/procedur, co jest niezwykle istotne dla badań prowadzonych na dużych obszarach. Należy pamiętać o roli GIS-u w procesie przygotowania i przetwarzania danych wejściowych oraz o jego znaczeniu praktycznym w interpretacji uzyskanych wyników.

W artykule zaprezentowano nowe narzędzie GIS, zwiększające funkcjonalność programu ArcGIS 10.1 -
ArcNEO. Służy ono do obliczania parametrów i wskaźników morfometrycznych. Następnie otrzymanym wartościom wskaźników przypisuje klasy aktywności, które są podstawą wyznaczenia stref mobilnych tektonicznie.

\section{Charakterystyczne cechy geologiczne i geomorfologiczne zlewni górnego Wieprza}

Zlewnia górnego Wieprza o powierzchni $410 \mathrm{~km}^{2}$ pod względem tektonicznym znajduje się w annopolsko-lwowskiej strefie szwu transeuropejskiego (TESZ), oddzielającego prekambryjski kraton wschodnioeuropejski od zachodnioeuropejskich struktur paleozoicznych (Znosko 1979). W planie waryscyjskim analizowany obszar usytuowany jest głównie w granicach paleozoicznego podniesienia radomsko-kraśnickiego (Żelichowski 1983, Narkiewicz 2007), a tylko jego niewielkie części - w rowie mazowiecko-lubelsko-dniestrzańskim. Obie jednostki tektoniczne mają rozciągłość NW-SE. Podniesienie jest oddzielone od rowu strefą uskoków, przesuniętych kulisowo, na linii Zamość-Rawa Ruska-Krechów (Chiżniakow, Żelichowski 1974). Według tektonicznego planu podkenozoicznego, obszar położony jest w niecce lubelsko-lwowskiej (Pożaryski 1974), stanowiącej południowy odcinek niecki brzeżnej. Utwory podkenozoiczne, wypełniające nieckę lubelsko-lwowską, należą głównie do dwóch megacykli sedymentacyjnych: środkowo-późnojurajskiego i górnokredowego (Świdrowska i in. 2008). Z morfologicznego punktu widzenia istotne są dość zróżnicowane cechy chemiczne i fizyczne skał górnokredowych, wpływające na ich właściwości litologiczne. Najpowszechniejsze i najbardziej zróżnicowane przestrzennie są wychodnie utworów mastrychtu dolnego (gezy, gezy margliste, opoki margliste i margle) oraz mastrychtu górnego (margle i opoki margliste z przewarstwieniami kredy piszącej) (Cieśliński i in. 1994). Najczęściej obserwowanymi nieciągłościami w odsłonięciach skał górnokredowych są uskoki normalne (na ogół wysokokątowe, z nachyleniem powierzchni uskokowej ku południowi; azymut biegu ok. $130^{\circ}$ ) oraz uskoki normalne o powierzchni uskokowej, nachylonej $\mathrm{ku}$ południowemu zachodowi (azymut biegu powierzchni uskokowej 210-230) (Margielewski, Jankowski 2011). Struktury te dzielą obszar dorzecza na wiele bloków o różnej wielkości. $Z$ powodu odnawiania przesunięć wzdłuż uskoków głębokiego podłoża (Brochwicz-Lewiński, Pożaryski 1986) bloki są nierównomiernie dźwigane (Harasimiuk 1980). Potwierdzają to wyniki powtarzanych pomiarów niwelacji precyzyjnej (m.in. Wyrzykowski 1987) oraz rozkład współczesnego pola naprężeń, wskazujący na działanie kompresji zorientowanej południkowo oraz tensji zgodnej z kierunkiem równoleżnikowym (Jarosiński 2006).

Utwory mioceńskie (płytkomorskie osady węglanowe i terygeniczne) są znacznie zniszczone i nie tworzą ciągłej pokrywy (Musiał 1987), budując najwyższe wzniesienia na dziale wodnym Wieprza i Sanu. 
Kompleks utworów czwartorzędowych obejmuje plejstoceńskie osady fluwioglacjalne, związane ze zlodowaceniami - południowopolskim i środkowopolskim, a także osady holoceńskie - eoliczne, limniczne, fluwialne, deluwialne i eluwialne - bardzo różnorodne pod względem genetycznym i wiekowym (Maruszczak, Świeca 2004). Znaczne obszary zajmują osady eoliczne (lessy i piaski), zróżnicowane regionalnie pod względem cech genetycznych i rozmieszczenia. Lessy tworzą niewielkie, lokalne pokrywy pomiędzy Obroczą i Krasnobrodem oraz Tarnawatką i Krynicami (Maruszczak 1980). Eoliczne piaski pokrywowe i piaski w wydmach są najbardziej powszechne zarówno w dnach dolin, jak i w dolnych partiach stoków, a niekiedy nawet na wzniesieniach wierzchowinowych (Superson 1989). Holoceńskie iły i piaski $\mathrm{z}$ domieszką substancji organicznej budują dno doliny Wieprza (Bałaga 1998).

Analizowana zlewnia cechuje się dużym zróżnicowaniem hipsometrycznym. Maksymalna deniwelacja, wyznaczona skrajnymi punktami: 386 m n.p.m. (Wapielnia) i $220 \mathrm{~m}$ n.p.m. (koryto Wieprza w Zwierzyńcu) osiąga 166 m. Średnia wysokość wynosi 288 m n.p.m.

\section{Dane}

Całość prac, związanych z przygotowaniem, opracowaniem i przetwarzaniem danych wejściowych, niezbędnych do szacowania młodej aktywności tektonicznej w zlewni górnego Wieprza, została podzielona na etapy:

1) wyznaczenie zlewni cząstkowych i ich klasyfikacja,

2) wyznaczenie profili poprzecznych zlewni, dla których obliczono wartości wskaźnika $V f$,

3) wygenerowanie cyfrowego modelu wysokościowego.

\section{Zlewnie}

Początkowy etap prac polegał na wyznaczeniu zlewni cząstkowych i ich klasyfikacji zgodnie z klasycznym modelem hydrograficznym. W pierwszej fazie wyseparowano zlewnie 3. rzędu w oparciu o Rastrową Mapę Podziału Hydrograficznego Polski (MPHP). W fazie drugiej na podstawie mapy topograficznej w skali 1:10 000, zostały wyznaczone i zdygitalizowane zlewnie 4.-9. rzędu, o powierzchniach większych niż $0,5 \mathrm{~km}^{2}$. W konsekwencji pozwoliło to na weryfikację przebiegu działów wodnych 3. rzędu, a także znaczne ich uszczegółowienie. Końcowym wynikiem prac była warstwa, w której znajdowały się wszystkie zlewnie, a jej tabela atrybutów zawierała informacje tylko o unikalnym numerze oraz rzędzie zlewni.

Przy zamykaniu zlewni zwracano uwagę na powierzchniowe utwory geologiczne oraz formy $\mathrm{z}$ nich zbudowane, w szczególności na wydmy. Założono, że wydmy o dużej powierzchni i kubaturze, cechujące się znaczną wysokością, umiejscowione często u wylotów dolin rzecznych oraz w obrębie ich działów wodnych, istotnie zmieniają parametry fizjograficzne i morfometryczne zlewni. Może się to przekładać na wyniki obliczeń i prowadzić do ich błędnej interpretacji. Zrezygnowano więc z wyznaczania zlewni w oparciu o cechy przestrzenne i wysokościowe tych form, ponieważ obszary przez nie zajęte mają genezę akumulacyjną. Weryfikacji tej dokonano na podstawie Szczegółowej Mapy Geologicznej Polski w skali 1:50 000 - arkusze: Tereszpol (Popielski 1992), Krasnobród (Kurkowski 1993), Komarów (Buraczyński, Superson 1997), Tomaszów Lubelski (Buraczyński i in. 1997), skalibrowanej w układzie PUWG 1992.

\section{Profile poprzeczne zlewni}

Profile poprzeczne zlewni, w których obliczano wartości wskaźnika $V f$, wyznaczono w odległości do około $1 \mathrm{~km}$ od strefy uskokowej, znaczonej na mapach i w opracowaniach geologicznych. W dalszych obliczeniach uwzględniono następujące cechy profilu: szerokość dna doliny, wysokość bezwzględną dna doliny oraz wysokości bezwzględne odpowiednio (tab. 1) prawego i lewego wododziału.

\section{Cyfrowy model wysokościowy (CMW)}

Trzeci etap prac polegał na wygenerowaniu cyfrowego modelu wysokościowego CMW (DEM, ang. - Digital Elevation Model) w oparciu o oprogramowanie ArcGIS 10.1. Model został opracowany na podstawie dwóch typów danych. Za pierwszy posłużyły dane fotogrametryczne w postaci nieregularnej siatki TIN (ang. Triangulated Irregular Network), które stanowią powszechnie wykorzystywane źródło informacji o rzeźbie terenu. $\mathrm{Na}$ ich podstawie, korzystając z narzędzia TIN to DEM, wygenerowano CMW o 5-metrowej rozdzielczości oczek siatki. Uzyskane wyniki porównano z dostępnym dla tego obszaru cyfrowym modelem wysokościowym, który został wygenerowany $\mathrm{z}$ zastosowaniem narzędzia Topo to Raster w oparciu o dane wejściowe - zdigitalizowane poziomice $\mathrm{z}$ map topograficznych $\mathrm{w}$ skali 1:10 000 . Na podstawie uzyskanych wyników oraz ich analizy wizualnej uznano, że CMW wygenerowany $z$ danych fotogrametrycznych znacznie lepiej odzwierciedla powierzchnię terenu na obszarach bezleśnych, natomiast CMW z map topograficznych jest dokładniejszy na obszarach leśnych. Brak danych wektorowych w skali 1:10 000 dla zlewni górnego Wieprza oraz duża jej powierzchnia zadecydowały, że w pierwszej kolejności zostały zdigitalizowane tylko poziomice na terenach leśnych. Na podstawie tych danych wygenerowano CMW o rozdzielczości $5 \mathrm{~m}$. Następnie przy użyciu narzędzia Mosaic to New Raster został on połączony z cyfrowym modelem wysokościowym $\mathrm{z}$ danych fotogrametrycznych. W konsekwencji otrzymano CMW o wielkości komórki $5 \mathrm{~m}$, który stanowił połączenie informacji uzyskanych z danych fotogrametrycznych (obszary niezalesione) oraz informacji zdygitalizowanych z map topograficznych (obszary zalesione). Błędy, jakie pojawiały się na łączeniu otrzymanych modeli, w postaci ,sztucznych granic nieciągłości”, uznane zostały za mało istotne. Nie wpływają one bowiem na wyniki obliczanych para- 
metrów i wskaźników, których wartości w sposób szacunkowy przekładają się na klasy aktywności tektonicznej.

Dotychczas w wielu opracowaniach korzystano z cyfrowych modeli wysokościowych o różnej rozdzielczości oczek siatki (5,0-40,0 m), generowanych z digitalizowanych poziomic $\mathrm{z}$ map topograficznych $\mathrm{w}$ różnych skalach: 1:10 000 (m.in. Badura, Przybylski 2005, Pedrera i in. 2009), 1:20 000 (Kouli i in. 2006), 1:24 000 (Harkins i in. 2005), 1:25 000 (Troiani, Della Seta 2008, D’Alessandro $i$ in. 2008, Faghih i in. 2012), 1:50 000 (Tsodoulos $i$ in. 2008, Pareta, Pareta 2011). Stosowano przy tym różne narzędzia: ArcGIS, Surfer, Globe Mapper, Mapinfo, SOI toposheets/ASTER (m.in. Badura, Przybylski 2005, Garrote i in. 2008, Figueroa, Knott 2010, Joshi i in. 2010, Pareta, Pareta 2011) w systemach informacji geograficznej, analizując morfotektoniczne cechy obszarów oraz obliczając parametry i wskaźniki opisujące zlewnie i zróżnicowanie wysokości w ich obrębie.

Na przykład w strefie sudeckiego uskoku brzeżnego obliczono morfometryczne parametry (obszar zlewni $A$, maksymalna długość zlewni $L$, obwód zlewni $P$, średnia szerokość zlewni $W$, maksymalna deniwelacja zlewni $H$ ) i wskaźniki (rzeźby $R h$, wydłużenia zlewni $R e$, kolistości zlewni $R k$, kształtu zlewni $R f$ ), opisujące zlewnie w oparciu o CMW wygenerowany z digitalizowanych poziomic z map topograficznych w skali 1:10 000 (Badura $\mathrm{i}$ in. 2003). W oparciu o CMW o 5-metrowej rozdzielczości oczek siatki, wygenerowany z wektorowych map Andaluzji w skali 1:10 000, obliczono morfometryczny wskaźnik kształtu doliny $V f$ dla zlewni w Betic Cordillera na południu Hiszpanii (García-Tortosa i in. 2008).

Rzadko stosowano jednakże tak dokładny CMW, częściej korzystano z cyfrowych modeli wysokościowych o mniejszej rozdzielczości oczek siatki. CMW o 10-metrowej rozdzielczości oczek siatki użyto do analizy geomorfometrycznej oraz do obliczenia wskaźnika kształtu doliny $V f$ w Betic Cordillera w południowej Hiszpanii (Pérez-Peña i in. 2010). Niekiedy wartości wskaźników morfometrycznych - planimetryczny wskaźnik kształtu zlewni $B s 1$, asymetrii zlewni $A F$ - obliczano, korzystając z CMW o 30-metrowej rozdzielczości dostępnego z United States Geological Survey (USGS) w zlewniach o podobnych powierzchniach $\left(1-5 \mathrm{~km}^{2}\right)$ i rzędach (2-3) (Harkins i in. 2005), a nawet o 40-metrowej rozdzielczości oczek siatki do obliczenia wskaźników zróżnicowania wysokości $H I$ (Chen i in. 2003). Wykorzystywano także dane SRTM (rozdzielczość $90 \mathrm{~m}$, http://srtm.csi.cgiar.org) do obliczania wskaźnika kształtu doliny $V f$ (Joshi i in. 2010). Niekiedy używano trzech cyfrowych modeli wysokościowych o różnych rozdzielczościach oczek siatki: 90 $\mathrm{m}$ do obliczania współczynnika krętości krawędzi Smf, zaś 30 i $10 \mathrm{~m}$ do obliczania wskaźników kształtu doliny $V f$ i rzeźby $R h$ w górach Sierra Nevada w Kalifornii (Figueroa, Knott 2010). Zatem CMW o rozdzielczości $5 \mathrm{~m}$ oczek siatki, wygenerowany dla zlewni górnego Wieprza, jest wystarczający do wyznaczenia stref aktywnych tektonicznie.

\section{ArcNEO - narzędzie do oceny młodej mobilności tektonicznej}

W oparciu o dostępne funkcje i narzędzia oprogramowania ArcGIS 10.1 zostało opracowane nowe narzędzie ArcNEO, które służy do wyznaczania klas młodej aktywności tektonicznej w oparciu o parametry i wskaźniki morfometryczne charakteryzujące zlewnie (tab. 1). Narzędzie ArcNEO ma postać skrzynki narzędziowej dodawanej do okna ArcToolbox (ryc. 1). W skrzynce tej znajduje się pięć modeli geoprzetwarzania: Twórz katalogi, Licz parametry, Licz wskaźniki, Licz Vf oraz model Licz Wmax. Pierwsze trzy stanowią kolejno następujące po sobie etapy, natomiast model Licz $V f$ działa niezależnie i służy do wyznaczania liniowego wskaźnika, opisującego cechy kształtu doliny w przyjętym przekroju poprzecznym zlewni. Model Wmax jest także autonomiczny i stanowi część modelu Licz parametry.

\section{Narzędzie ArcNEO - parametry}

Model Twórz katalogi w pierwszej kolejności tworzy katalogi i podkatalogi oraz geobazę, w których przechowywane są dane tymczasowe (warstwy wektorowe oraz rastry), generowane w trakcie pracy modelu, dane pośrednie (warstwy wektorowe) zawierające wartości parametrów oraz dane wynikowe (warstwy wektorowe) z wartościami wskaźników i klas aktywności tektonicznej.

Kolejny model Licz parametry generuje wybrane wartości parametrów wysokościowych i geometrycznych zlewni na podstawie CMW oraz warstwy wektorowej z zasięgiem zlewni (ryc. 2). W wyniku działania tego modelu generowane są następujące warstwy pośrednie: $P K \min$ - zawiera punkty o minimalnej wysokości w korycie zlewni; PDmax - punkty najbardziej oddalone od punktów o minimalnej wysokości w korycie zlewni (PKmin); $L$ - proste łączące punkty PKmin i PDmax, będące jednocześnie maksymalnymi długościami zlewni; Wmax - proste, które są maksymalnymi szerokościami

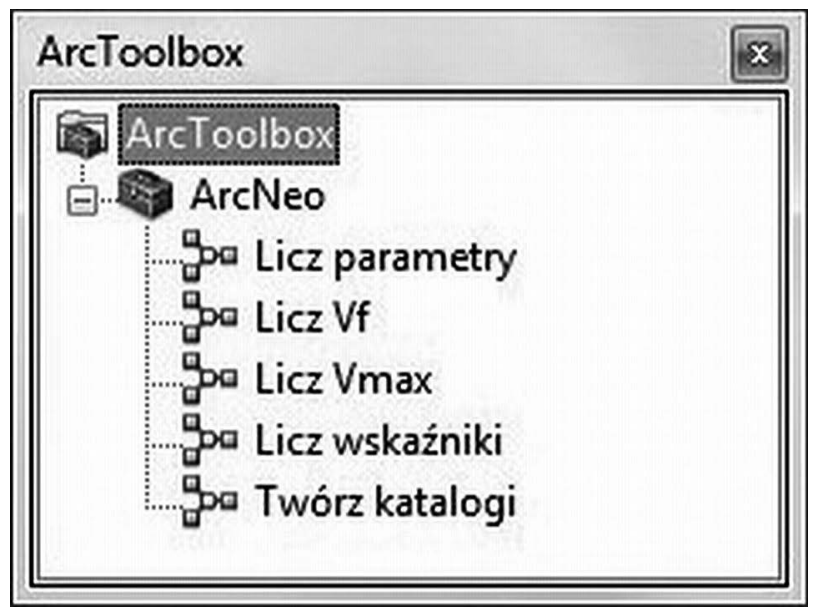

Ryc. 1. Skrzynka narzędziowa ArcNEO w oknie ArcToolbox programu ArcGIS

Fig. 1. ArcNEO toolbox in the ArcToolbox window of the ArcGIS software 
Tabela 1. Wybrane morfometryczne parametry i wskaźniki, charakteryzujące wysokości i geometrię zlewni oraz wskaźniki liniowe, opisujące cechy form rzeźby

Table 1. Selected morphometric parameters and indicators of catchment elevations and geometry, and linear indicators of terrain relief

\begin{tabular}{|c|c|c|c|}
\hline Parametr/wskaźnik & Symbol & Wzór & Źródło \\
\hline \multicolumn{4}{|c|}{ Parametry podstawowe i wskaźniki charakteryzujące wysokości w zlewni } \\
\hline Obszar (powierzchnia) zlewni & $\mathrm{A}\left[\mathrm{km}^{2}\right]$ & & Horton (1945) \\
\hline Obwód zlewni & $\mathrm{P}[\mathrm{km}]$ & & Smith (1950) \\
\hline Maksymalna długość zlewni & $\mathrm{L}[\mathrm{km}]$ & & Horton (1945) \\
\hline Wysokość maksymalna & $\mathrm{H}_{\max }[\mathrm{m} \mathrm{n} . \mathrm{p} . \mathrm{m}]$. & & \\
\hline Wysokość minimalna & $\mathrm{H}_{\min }[\mathrm{m}$ n.p.m. $]$ & & \\
\hline Różnica wysokości ekstremalnych & $\mathrm{H}[\mathrm{m}]$ & $\mathrm{H}_{\max }-\mathrm{H}_{\min }$ & Strahler (1954) \\
\hline Średnia arytmetyczna wysokość & $\mathrm{H}_{\text {sred. }}[\mathrm{m}$ n.p.m.] & $\Sigma\left[\mathrm{H}_{1}+\mathrm{H}_{2}+\ldots+\mathrm{H}_{\mathrm{n}}\right] / \mathrm{n}$ & \\
\hline Wskaźnik rzeźby/urzeźbienia & $\mathrm{Rh}(\mathrm{RR})$ & $\mathrm{H} / \mathrm{L}$ & Strahler (1954) \\
\hline Wskaźnik wysokości względnych & Rhp & $\mathrm{H} / \mathrm{P}$ & Melton (1958) \\
\hline \multicolumn{4}{|c|}{ Parametry i wskaźniki charakteryzujące geometrię zlewni } \\
\hline Maksymalna szerokość zlewni & Wmax & & Cannon (1976) \\
\hline Średnia szerokość zlewni & $\mathrm{W}[\mathrm{km}]$ & $\mathrm{A} / \mathrm{L}$ & \\
\hline Wskaźnik kolistości zlewni & Rk & $4 \pi \mathrm{A} / \mathrm{P}^{2}$ & Miller (1953) \\
\hline Wskaźnik zwartości zlewni & $\mathrm{Bc}$ & $\mathrm{P} / \mathrm{A}$ & $\begin{array}{l}\text { Engstrom } \\
(1989)\end{array}$ \\
\hline Wskaźnik wydłużenia zlewni & $\operatorname{Re}$ & $2(\mathrm{~A} / \pi)^{0.5} / \mathrm{L}$ & Schumm (1954) \\
\hline Wskaźnik kształtu zlewni & $\mathrm{Rf}$ & $\mathrm{A} / \mathrm{L}^{2}$ & Horton (1945) \\
\hline Wskaźnik lemniskaty & $\mathrm{k}$ & $\pi \mathrm{L}^{2} / 4 \mathrm{~A}$ & Chorley (1971) \\
\hline Wskaźnik kształtu zlewni & $\mathrm{Bs}_{2}$ & $\mathrm{~L}^{2} / \mathrm{A}$ & Singh (1988) \\
\hline Planimetryczny wskaźnik kształtu zlewni & $\mathrm{Bs}_{1}$ & $\mathrm{~L} / \mathrm{Wmax}$ & Cannon (1976) \\
\hline Wskaźniki liniowe opisujące cechy form rzeźby w zlewniach & & & \\
\hline $\begin{array}{l}\text { Współczynnik kształtu doliny (szerokości dna-wysokości zboczy } \\
\text { doliny) }\end{array}$ & Vf & $\begin{array}{c}2 \mathrm{Vfw} /[(\mathrm{Eld}-\mathrm{Esc})+(\text { Erd }- \\
\text { Esc })]\end{array}$ & Bull (1977) \\
\hline
\end{tabular}

Vfw - szerokość dna doliny, Eld - wysokość [m n.p.m.] lewego wododziału, Erd - wysokość [m n.p.m.] prawego wododziału, Esc - wysokość [m n.p.m.] dna doliny

$\mathrm{Vfw}$ - valley floor width, Eld - elevation ( $\mathrm{m}$ a.s.1.) of the left divide, Erd - elevation (m a.s.1.) of the right divide, Esc - elevation ( $\mathrm{m}$ a.s.1.) of the valley floor

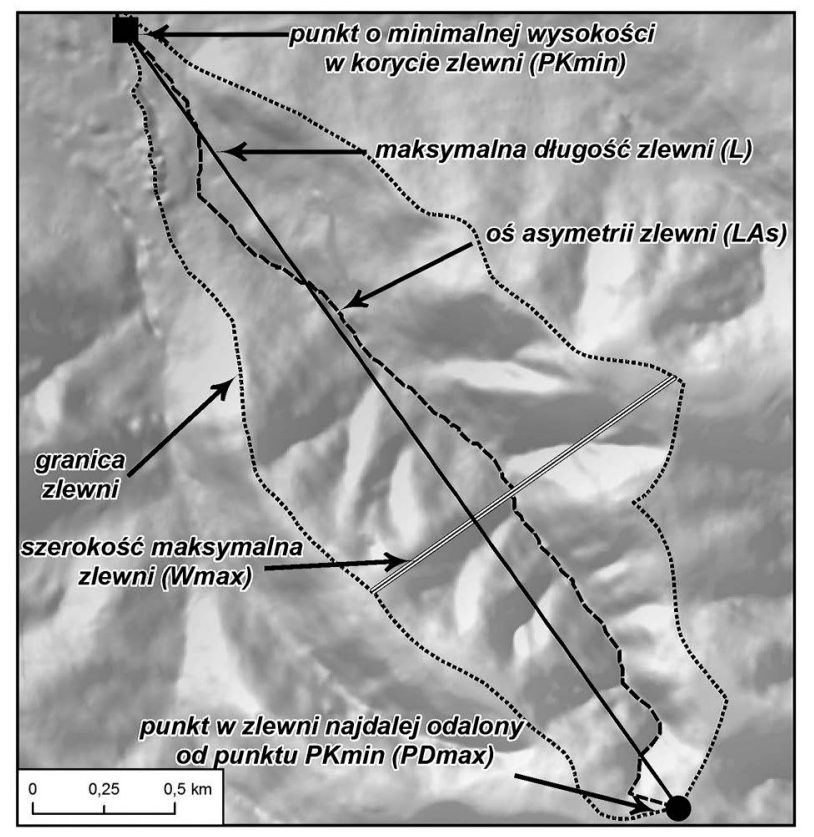

Ryc. 2. Wybrane parametry morfometryczne, obliczane w zlewni modelem Licz parametry narzędzia ArcNEO

Fig. 2. Selected morphometric parameters calculated for the catchment with the Count parameters model of the ArcNEO tool zlewni; $L A s$ - linie asymetrii rozdzielające zlewnie na części prawo- i lewostronne. Model ten dla każdej zlewni wyznacza także: powierzchnię zlewni $A$, powierzchnię prawej $(A p)$ oraz lewej $(A l)$ części zlewni, obwód $P$ oraz maksymalną deniwelację $H$. Wynikiem działania tego modelu jest jedna warstwa, zawierająca wszystkie analizowane zlewnie wraz $\mathrm{z}$ tabelą atrybutów, w której przechowywane są wartości obliczonych parametrów. Warstwa ta, w następnym etapie działań, jest elementem wejściowym modelu Licz wskaźniki.

Model Licz Wmax stanowi jedno z narzędzi modelu Licz parametry i wyznacza maksymalną szerokość w zlewni. Tak przyjęte rozwiązanie jest wynikiem ograniczeń, jakie funkcjonują w aplikacji ModelBuilder i nie pozwalają na wielokrotne używanie funkcji iteracyjnych w pojedynczym modelu.

\section{Narzędzie ArcNEO - wskaźniki}

Model Licz wskaźniki w kolejnych etapach geoprzetwarzania wykonuje operacje w oparciu o tabelę atrybutów z wcześniej wyznaczonymi parametrami. Kolejno, na podstawie uzyskanych parametrów, model oblicza wartości wskaźników: rzeźby $R h$, wysokości względnych $R h p$, średniej szerokości zlewni $W$, wydłużenia zlewni $R e$, kolistości $R k$, lemniskaty $k$, kształtu zlewni $R f$, kształtu 
zlewni $B s_{2}$, zwartości zlewni $B c$ oraz planimetrycznego wskaźnika kształtu zlewni $B s_{l}$. Na podstawie przedziałów wartości parametrów i wskaźników prezentowanych w literaturze otrzymane wartości parametrów i wskaźników są klasyfikowane w trzystopniowej skali; wartością 1 oznacza się zlewnie aktywne tektonicznie, wartością 2 zlewnie średnio aktywne, natomiast wartością 3 - zlewnie słabo aktywne lub nieaktywne. W zależności od specyfiki obszaru badań, jego opracowania i dostępnych informacji można także wyznaczyć niezależne przedziały w oparciu o analizę histogramu, co wykonano dla zlewni górnego Wieprza (tab. 2). W ostatnim etapie obliczeń model powtórnie wykonuje operację klasyfikacji wartości wskaźników w celu nadania im wag punktowych. Jest ona odwrotnie proporcjonalna do klas aktywności tektonicznej; 1 punkt przypisywany jest zlewniom słabo aktywnym lub nieaktywnym, 2 punkty - zlewniom średnio aktywnym, zaś 3 punkty - zlewniom aktywnym tektonicznie.

Model Licz Vf generuje warstwę punktową obrazującą wartość wskaźnika $V f$ w oparciu o CMW oraz warstwy wektorowe, charakteryzujące granice zlewni, szerokość dna doliny, a także przebieg profilu poprzecznego doliny w wyznaczonym przekroju poprzecznym zlewni.

\section{Narzędzie ArcNEO - sposoby wyznaczenia stref podlegających współcześnie względnemu dźwiganiu}

W niniejszym opracowaniu, w celach porównawczych, na etapie roboczym zastosowano dwa sposoby wyznaczenia stref podlegających współcześnie względnemu dźwiganiu. El Hamdouni i in. (2008) zaproponowali wskaźnik względnej aktywności tektonicznej (Iat), liczony na podstawie średniej wartości punktów uzyskanych z podzielenia sumy punktów $S$, przypisanych przedziałom wartości każdego z sześciu policzonych wskaźników, przez liczbę $N$ tych wskaźników. W ten sposób otrzymane średnie wielkości wskaźnika Iat zostały przypisane czterem klasom aktywności tektonicznej: 1 - bardzo wysokiej $(1,0 \leq$ Iat $<1,5)$; 2 - wysokiej $(1,5 \leq$ Iat $<2,0)$; 3 - średniej $(2,0 \leq$ Iat $<2,5)$ i 4 - niskiej $(2,5 \leq$ Iat $)$ (tab. 3). Brzezińska-Wójcik i in. (2010) wykonali sumaryczne zestawienie wartości wskaźników $R e, R k, R f, k$, na podstawie którego pokazali przestrzenne zróżnicowanie natężenia aktywności tektonicznej w analizowanych zlewniach. Do zestawienia przyjęto następujące założenia: dla wartości współczynników w przedziałach $0,00-0,50(R e)$ i $0,00-0,25(R k)$ przyjęto po 3 punkty, następnie odpowiednio: dla $0,50-0,75$ i $0,25-0,50$ - po 2 punkty oraz dla $0,75-1,00$ i $0,50-1,00$ - po 1 punkcie.

Podczas typowania obszarów dźwiganych w zlewni górnego Wieprza postępowano etapami, biorąc pod uwagę zróżnicowanie jakościowe parametrów zlewni. W etapie pierwszym wyznaczano strefy aktywizowane tektonicznie na podstawie sumy skumulowanych punktów przypisanych wskaźnikom, opisującym wysokości w zlewniach $(R h, R h p)$. Dzięki temu uzyskano przestrzenny obraz rozmieszczenia zlewni o względnie dużej aktywności tektonicznej (największa 6 punktów), słabej (5-4 punkty) oraz bardzo słabej/braku (3 punkty) mobilności. Następnie w ten sam sposób kolejno przeanalizowano oddzielnie poszczególne grupy wskaźników (tab. 3).

W ostatnim etapie obliczono wskaźnik względnej aktywności tektonicznej (WZAT/Iat) na podstawie skumulowanych sum punktów według prostszych zasad El Hamdouni i in. (2008), nie uwzględniając wskaźników HI oraz $A F$. Wartości tych wskaźników potraktowano jako pomocnicze podczas ostatecznego typowania stref dźwiganych współcześnie z różną prędkością. Oddzielnie także przeanalizowano wartości wskaźnika $V f$ w odniesieniu do wartości prędkości dźwigania obszaru podawanych przez Rockwella i in. (1985) i Bulla (2007) (tab. 3).

$\mathrm{Na}$ koniec, wykorzystując grupowanie wariancyjne, określono wskaźnik względnej aktywności tektonicznej (WZAT/Iat) i przedstawiono (ryc. 3) uskoki i strefy względnie aktywne tektonicznie.

\section{Wyniki}

W oparciu o nowe narzędzie ArcNEO oraz CMW dla zlewni górnego Wieprza obliczono trzy grupy wskaźników: dwie (wysokościowe i powierzchniowe) opisujące parametry zlewni oraz jedną (liniową) opisującą cechy form rzeźby. Obliczone parametry liniowe obejmowały wskaźnik $V f$ (szerokość dna-wysokość zboczy), określający cechy dolin w przekroju poprzecznym w odległości około $1 \mathrm{~km}$ od strefy uskokowej. Wszystkie wymienione parametry i wskaźniki obliczono dla 161 zlewni cząstkowych 3.-9. rzędu (o powierzchniach w przedziale od 0,5 do $15 \mathrm{~km}^{2}$ ) górnego Wieprza, obszaru stosunkowo dobrze rozpoznanego pod względem geologicznym (Buraczyński 1996, Superson 1996, Brzezińska-Wójcik, Superson 2004, Maruszczak, Świeca 2004). Następnie, w oparciu o sumę skumulowanych punktów przypisanych wskaźnikom, obliczono wielkości wskaźnika WZAT/Iat, które były podstawą wydzielenia obszarów aktywnych (dźwiganych) współcześnie. Ponadto, w zależności od cech ujawniających się w rzeźbie terenu, w zlewni górnego Wieprza wyróżniono względnie aktywne uskoki o znaczeniu pierwszorzędnym lub drugorzędnym, dla których oszacowano prędkości dźwigania na około 0,05-0,50 $\mathrm{mm} \mathrm{a}^{-1}$, uwzględniając wartości wskaźnika $V f$.

Spośród uskoków 1. rzędu uwagę zwraca uskok górnego Wieprza pomiędzy ujściem Jacynki a Bondyrzem. Na jego aktywność wskazują wartości wskaźnika $V f<1,00$. Potwierdzają to inne kryteria: morfolineament $\left(80-100^{\circ}\right)$; zwiększony spadek doliny w profilu podłużnym w strefie uskoków mezozoiczno-kenozoicznych oraz związana z nimi lokalizacja źródlisk; wypukły profil podłużny doliny; lica trójkątne na zboczach doliny (Brzezińska-Wójcik 2013). Na podstawie analizy wysokości położenia teras wysokiej i średniej, zbudowanych z osadów datowanych na młodszą część interstadiału grudziądza (Superson 1996), oszacowano prędkość dźwigania na około $0,30 \mathrm{~mm} \mathrm{a}^{-1}$.

Spośród uskoków wyróżnionych na podstawie innych kryteriów (morfolineament $50-80^{\circ}$, lica trójkątne w stre- 


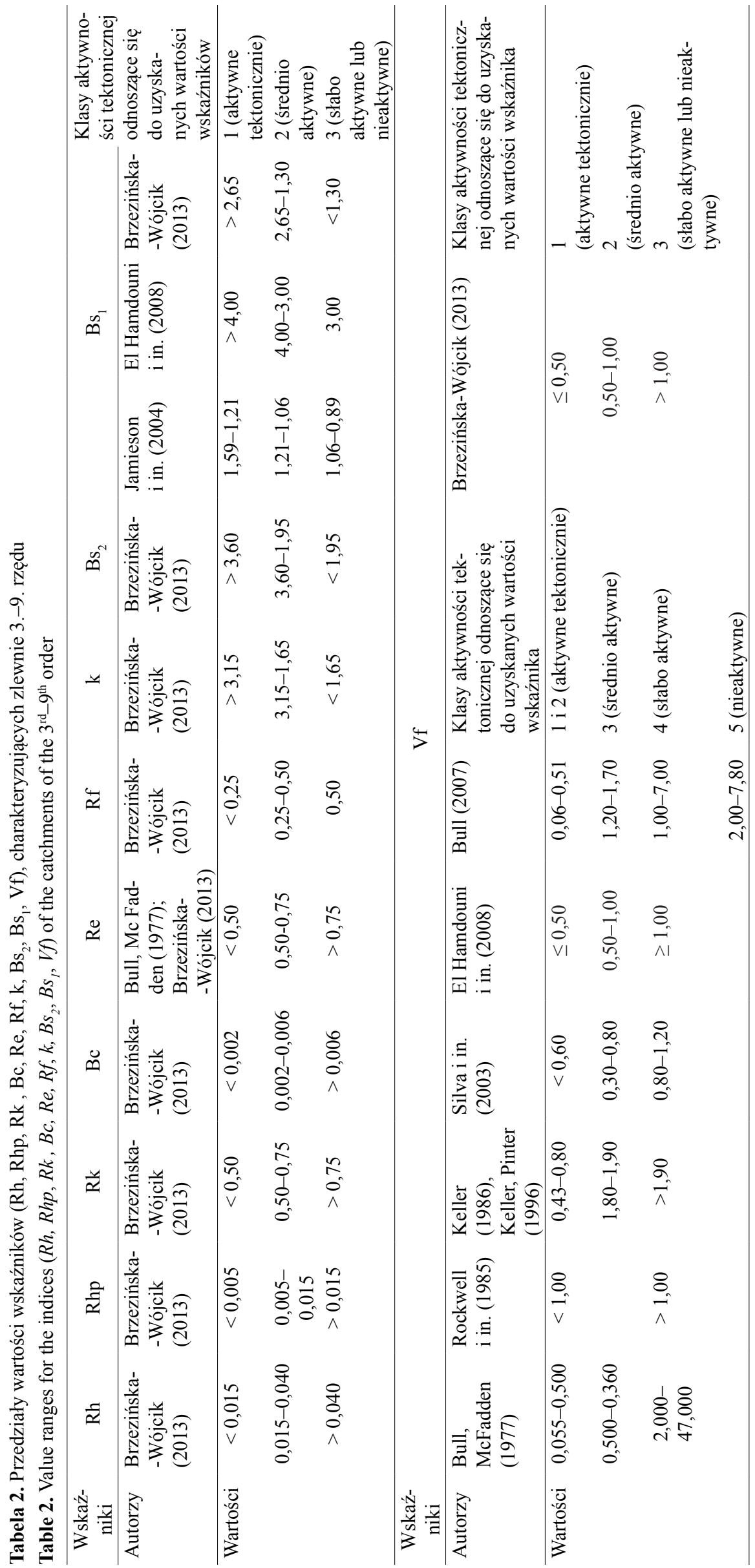


Tabela 3. Wskaźnik względnej aktywności tektonicznej (WZAT/Iat) na podstawie skumulowanych sum punktów według wartości wskaźników opisujących wysokości i geometrię zlewni 3.-9. rzędu

Table 3. Indicator of relative tectonic activity (WZAT/Iat) based on cumulative sums of points according to values of indicators of elevations and geometry of catchments of the $3^{\text {rd }}-9^{\text {th }}$ order

\begin{tabular}{|c|c|c|c|c|c|c|c|c|}
\hline \multirow[b]{3}{*}{ 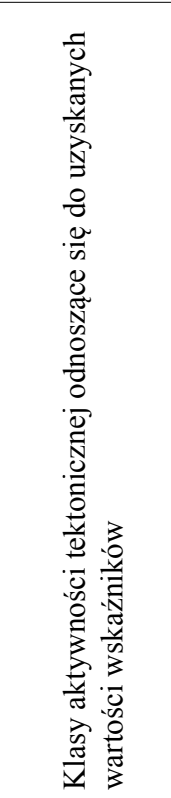 } & \multicolumn{8}{|c|}{ Wskaźnik względnej aktywności tektonicznej (WZAT/Iat) } \\
\hline & \multicolumn{3}{|c|}{ Etapy cząstkowe } & \multicolumn{5}{|c|}{ Etap końcowy } \\
\hline & 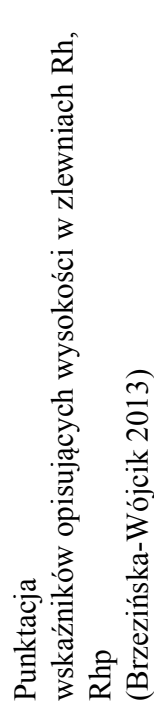 & 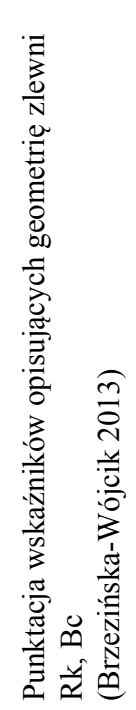 & 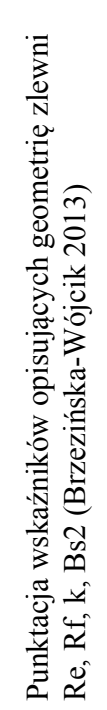 & 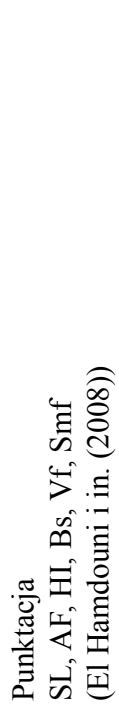 & 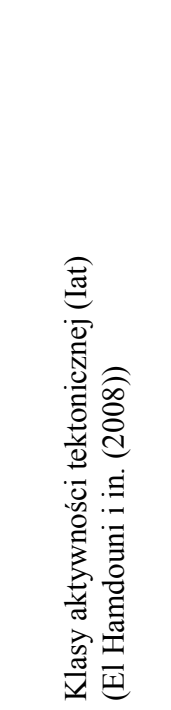 & 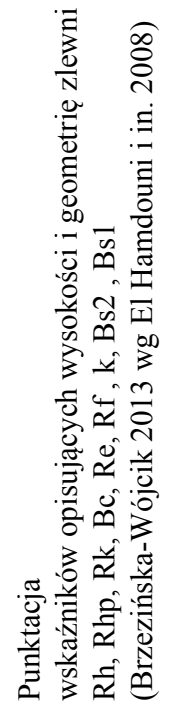 & 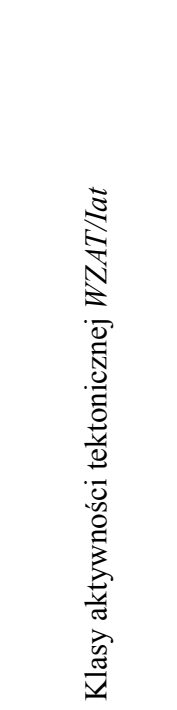 & 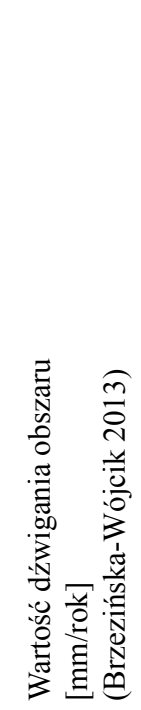 \\
\hline 1 (aktywne) & 6 & 6 & $15-13$ & $1,0-1,5$ & $\begin{array}{l}1 \text { (bardzo } \\
\text { aktywne) }\end{array}$ & $1,0-1,5$ & 1 (aktywne) & $0,40-0,50$ \\
\hline $\begin{array}{l}2 \text { (średnio } \\
\text { aktywne) }\end{array}$ & $5-4$ & $5-4$ & $12-9$ & $1,5-2,0$ & 2 (aktywne) & $1,5-2,0$ & $\begin{array}{l}2 \text { (średnio } \\
\text { aktywne) }\end{array}$ & $0,50-0,05$ \\
\hline \multirow[t]{2}{*}{$\begin{array}{l}3 \text { (słabo } \\
\text { aktywne lub } \\
\text { nieaktywne) }\end{array}$} & 3 & 3 & $8-5$ & $2,0-2,5$ & $\begin{array}{l}3 \text { (średnio } \\
\text { aktywne) }\end{array}$ & $2,0-2,5$ & $\begin{array}{l}3 \text { (słabo } \\
\text { aktywne) }\end{array}$ & \multirow{2}{*}{0,05} \\
\hline & & & & $>2,5$ & $\begin{array}{l}4 \text { (słabo } \\
\text { aktywne) }\end{array}$ & $2,5-3,0$ & $\begin{array}{l}4 \text { (nieaktyw- } \\
\text { ne) }\end{array}$ & \\
\hline
\end{tabular}

fie ujść dolin odwadniających prawe skrzydło zlewni Kosobud) uwagę zwraca strefa uskokowa Kosobud. Na jej aktywność wskazują wartości wskaźnika $V f<1,00$.

$\mathrm{Na}$ podstawie wielkości wskaźnika WZAT/Iat, w nawiązaniu do wyróżnionych aktywizowanych uskoków, wyznaczono aktywne współcześnie obszary dźwigane z podobną prędkością (ryc. 3). W granicach zlewni górnego Wieprza wyróżniają się bloki: Zaboreczna, Tarnawatki, Malewszczyzny, Bondyrza, Pańkowa, Szuru, Adamowa, Grabnika, Kosobud i Szozd, dźwigane z prędkością oko-

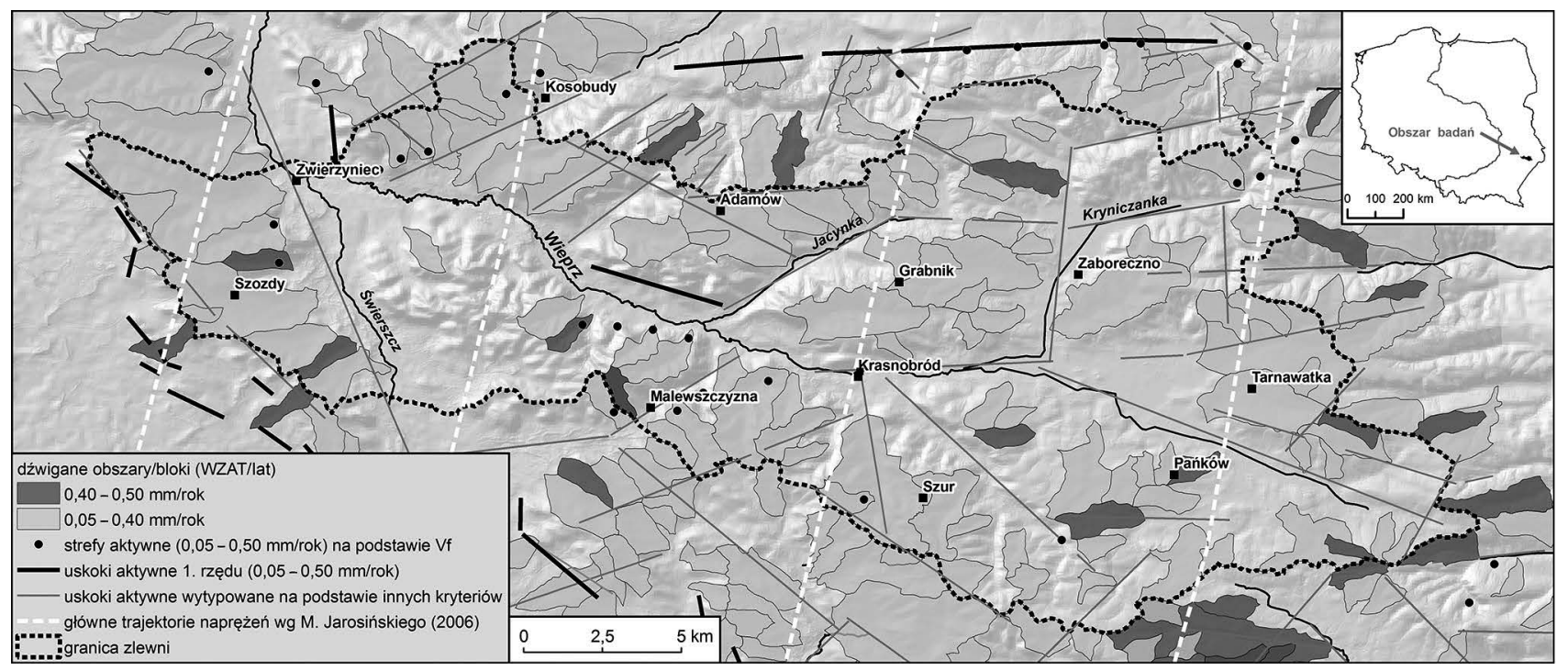

Ryc. 3. Zastosowanie ArcNEO w zlewni górnego Wieprza

Fig. 3. Application of ArcNEO in the upper Wieprz catchment 
ło $0,05-0,50 \mathrm{~mm} \mathrm{a}^{-1}$, oszacowaną w oparciu o wielkość wskaźnika WZAT/Iat (tab. 3). O względnej aktywności bloków Zaboreczna i Tarnawatki można ponadto wnioskować na podstawie: najwyższej maksymalnej deniwelacji H (>78,0 m); największej sumy skumulowanych punktów przyznanych najniższym wskaźnikom kolistości zlewni $R k$ i zwartości zlewni $B c$. Na względne dźwiganie bloków Malewszczyzny i Bondyrza wskazują najwyższe wartości maksymalnej deniwelacji $H(>78,0 \mathrm{~m}) \mathrm{w}$ zlewniach asymetrycznych. Bloki Pańkowa i Szuru można uznać za aktywne na podstawie najniższych wartości wskaźników rzeźby $R h(<0,015)$ i wysokości względnych $R h p(<0,005)$ oraz największej sumy skumulowanych punktów przyznanych najniższym wskaźnikom kolistości zlewni $R k$ i zwartości zlewni $B c$. Wielkość dźwigania potwierdzają obliczenia uwzględniające miąższość strefy bezerozyjnej (średnio ok. $35 \mathrm{~m}$ ), przy założeniu, że procesy erozyjne zachodzą tutaj od około 240000 lat (po akumulacji lessu II, $237000 \pm 35000$ [Lub-334], Butrym, Superson 1987). Wynika z nich, że obszar może być dźwigany z prędkością $0,18-0,40 \mathrm{~mm} \mathrm{a}^{-1}$. Na około $0,10-$ $0,40 \mathrm{~mm} \mathrm{a}^{-1}$ można oszacować prędkość dźwigania bloków Adamowa, Grabnika i Kosobud na podstawie miąższości strefy bezerozyjnej. Na ich względną aktywność wskazują ponadto: grzbiety zagradzające; lica trójkątne ujawniające bieg uskoków mezozoiczno-kenozoicznych zorientowanych południkowo; asymetria dolin w przekroju poprzecznym oraz zlewnie asymetryczne (osie symetrii niekiedy zorientowane są poprzecznie lub skośnie do biegu uskoków w podłożu mezozoicznym) (Brzezińska-Wójcik 2013). O względnej aktywności bloku Szozd można wnioskować na podstawie największej sumy skumulowanych punktów przyznanych najniższym wskaźnikom kolistości zlewni $R k$ i zwartości zlewni $B c$. Na dźwiganie obszaru wskazują też inne przesłanki: pierzaste układy dolin i wąwozów $\left(210^{\circ}\right.$ i $\left.310^{\circ}\right)$, ujścia przeciwprądowe związane z kierunkiem $320^{\circ}$ (NW-SE), asymetria zboczy dolin, lica trójkątne na zboczach dolin o przebiegu SE-NW. Na podstawie obliczeń uwzględniających miąższość strefy bezerozyjnej (średnio ok. $55 \mathrm{~m}$ ), przy założeniu, że procesy erozyjne zachodzą tutaj od około $11 \mathrm{mln}$ lat (po sarmacie), można przyjąć, że prędkość dźwigania obszaru mieści się w zakresie 0,005-0,400 mm a $\mathrm{mm}^{-1}$ (Brzezińska-Wójcik 2013).

Aktywizacja tektoniczna uskoków oraz obszarów może się wiązać z naciskiem bloku ALCAPA (Alpy-Karpaty-Pannonia) ku NNE i NE na platformę, wywołującym kompresję naskórkową (Jarosiński 2006), a także ze zjawiskami relaksacji naprężeń szczątkowych związanych z potencjałem grawitacyjnym (Jaroszewski, Piątkowska 1988; Jaroszewski 1994) oraz ze wzrostem/spadkiem naprężeń w podłożu pod wpływem nacisku lądolodu na obszar o niewygasłych całkowicie mioceńsko-plioceńskich impulsach tektonicznych (Kosmowska-Suffczyńska 1986, Liszkowski 1993).

\section{Podsumowanie}

W artykule przedstawiono schemat działania narzędzia ArcNEO oraz scharakteryzowano poszczególne etapy prac nad oceną młodej aktywności tektonicznej w zlewni górnego Wieprza. Narzędzie ArcNEO zostało opracowane $\mathrm{z}$ wykorzystaniem aplikacji ModelBuilder. ArcNEO tworzy zestaw narzędzi zawierających pięć modeli geoprzetwarzania, przy czym schemat kolejno następujących po sobie operacji jest podzielony na trzy etapy, co powoduje, że tylko 3 spośród 5 modeli są uruchamiane w odpowiedniej kolejności. Najpierw tworzone są katalogi, które służą do przechowywania danych pośrednich oraz wyników końcowych. W kolejnych etapach wyznaczane są wybrane parametry oraz wskaźniki morfometryczne w zlewniach, a następnie - otrzymane wartości wskaźników przypisywane są klasom aktywności tektonicznej. Model Licz Vf działa niezależnie i służy do wyznaczania liniowego wskaźnika, opisującego cechy kształtu doliny w przyjętym przekroju poprzecznym zlewni. Model Wmax jest także autonomiczny i stanowi część modelu Licz parametry. Dane wejściowe stanowi CMW oraz warstwy wektorowe, charakteryzujące granice zlewni, szerokość dna doliny oraz przebieg profilu poprzecznego w zlewni, w którym obliczana jest wartość $V f$.

Otrzymane wyniki można odnosić do stosunkowo dobrze rozpoznanych ciągłych i nieciągłych struktur geologicznych oraz granic litostratygraficznych na całym Roztoczu (Brzezińska-Wójcik 2013). Przestrzenne rozmieszczenie skumulowanych wag punktowych wszystkich liczonych wskaźników można też porównywać z danymi dotyczącymi: współczesnego pola naprężeń, monitoringu grawimetrycznego, pomiarów gradientu geotermicznego, zmian parametrów pola grawitacyjnego oraz przejawów sejsmiczności. Można je także zestawiać z danymi hydrogeologicznymi (wartości współczynnika filtracji, rozmieszczenie źródeł oraz ich wydajność, m.in. Malinowski 1993). Ponadto można je porównywać z danymi geomorfologicznymi, np. deformacjami profilu podłużnego rzeki, zmianami w rozwinięciu koryta rzecznego oraz zmianami cech i miąższości aluwiów, rozmieszczeniem dolin zawieszonych, a także asymetrią kształtu dolin i sekwencją osadów w stożkach napływowych (Brzezińska-Wójcik, Superson 2004). Na tej podstawie można wyróżniać obszary o względnie podwyższonej współczesnej aktywności tektonicznej.

$\mathrm{O}$ zastosowaniu narzędzia ArcNEO w badaniach związanych nie tylko z młodą aktywnością tektoniczną, ale także w dziedzinach, w których wykorzystuje się charakterystyki fizjograficzne zlewni, decyduje brak wolnego dostępu do narzędzi o zbliżonej funkcjonalności w środowisku ArcGIS oraz możliwość jego użycia w innych obszarach o względnie jednorodnych cechach litologicznych. 


\section{Literatura}

Ascione A., Cinque A., Miccadei E., Villani F., Berti C., 2008. The Plio-Quaternary uplift of the Apennine chain: New data from the analysis of topography and river valleys in Central Italy. Geomorphology 102(1): 105-118, DOI: 10.1016/j.geomorph.2007.07.022.

Badura J., Przybylski B., 2005. Application of digital elevation models to geological and geomorphological studies - some examples. Przegląd Geologiczny 53(10/2): 977-983.

Badura J., Zuchiewicz W., Górecki A., Sroka W., Przybylski B., 2003. Morfometria strefy sudeckiego uskoku brzeżnego między Złotym Stokiem a Dobromierzem. Przegląd Geologiczny 51(12): 1048-1057.

Bałaga K., 1998. Rozwój torfowisk postglacjalnych w okolicy Krasnobrodu na Roztoczu ze szczególnym uwzględnieniem wskaźników działalności człowieka. Przegląd Geologiczny 46(9): 881-886.

Birot P., 1955. Les Methodes de la Morphologie. Presses Universite de France, Paris.

Bolca M., Altinbas U., Kurucu Y., Esetlili M.T., 2005. Determination of change detection of landscape of the Kucuk meanders delta using GIS and the remote sensing techniques. Journal Applied Sciences 5: 659-665.

Brochwicz-Lewiński W., Pożaryski W., 1986. Ewolucja rowu środkowopolskiego w permo-mezozoiku i kenozoiku. Materiały sympozjum „Historia ruchów tektonicznych na ziemiach polskich. Cykl alpejski”. Kraków: 8-9.

Brzezińska-Wójcik T., 2013. Morfotektonika annopolsko-lwowskiego segmentu pasa wyżynnego w świetle analizy cyfrowego modelu wysokościowego oraz wskaźników morfometrycznych. Wyd. UMCS, Lublin.

Brzezińska-Wójcik T., Superson J., 2004. Neotectonic conditions of sedimentation and erosion in small fluvial basins of the Roztocze Tomaszowskie (south-eastern Poland). Zeitschrift für Geomorphologie 48(2): 167-184.

Brzezińska-Wójcik T., Chabudziński Ł., Gawrysiak L., 2010. Neotectonic mobility of the Roztocze region, Ukrainian part, Central Europe: insights from morphometric studies. Annales Societatis Geologorum Poloniae 80(2): 167-183.

Bull W.B., 1977. Tectonic geomorphology of the Mojave Desert. U.S. Geological Survey Contract Report 14-08-001-G-394/Office of Earthquakes, Volcanoes and Engineering, Menlo Park, California.

Bull W.B., 2007. Tectonic Geomorphology of Mountains. A New Approach to Paleoseismology. Blackwell Publishing, Malden, MA.

Bull W.B., Mc Fadden L.D., 1977. Tectonic geomorphology north and south of the Garlock fault, California. W: D.O. Doehring (red.), Geomorphology in Arid Regions. Proceedings of the 8th Annual Geomorphology Symposium, State University of New York at Binghampton, 9: 115-138.

Buraczyński J., 1996. Ewolucja doliny górnego Wieprza na Roztoczu w piętrach wisły i holocenu. Annales UMCS B 60: 117-139.

Buraczyński J., Superson J., 1997. Szczegółowa Mapa Geologiczna Polski 1:50 000, arkusz Komarów (895). Wydawnictwo Państw. Inst. Geol. (2002), Warszawa.

Buraczyński J., Brzezińska-Wójcik T., Superson J., 1997. Szczegółowa Mapa Geologiczna Polski 1:50 000, arkusz Tomaszów Lubelski (928). Wydawnictwo PIG (2002), Warszawa.

Cannon P.J., 1976. Generation of explicit parameters for a quantitative geomorphic study of the Mill Creek drainage basin. Oklahoma Geology Notes 36, 1: 3-16.

Cieśliński S., Kubica B., Rzechowski J., 1994. Mapa geologiczna Polski. 1:200 000, arkusz Tomaszów Lubelski, Dołhobyczów. B - Mapa bez utworów czwartorzędowych. Wydawnictwo Kartograficzne Polskiej Agencji Ekologicznej S.A. (1996), Warszawa.

Chen Y.-C., Sung Q., Cheng K.-Y., 2003. Along-strike variations of morphotectonic features in the Western Foothills of Taiwan: tectonic implications based on stream-gradient and hypsometric analysis. Geomorphology 56: 109-137, DOI: 10.1016/S0169-555X(03)00059-X.

Chiżniakow A.W., Żelichowski A.M., 1974. Zarys tektoniki obszaru lubelsko-lwowskiego. Kwartalnik Geologiczny 18(4): 707-719.

Chorley R.J., 1971. The drainage basin as a fundamental geomorphic unit. W: R.J. Chorley (red.), Introduction to Physical Hydrology. Methuen, London: 37-59.

Clarke J.I., 1966. Morphometry from Maps. W: G.H. Dury (red.), Essays in geomorphology. N.Y. American Els. Publ. Comp.: 235-274.
Codilean A.T., Bishop P., Hoey T.B., 2006. Surface process models and the links between tectonics and topography. Progress in Physical Geography 30: 307-333. DOI: 10.1191/0309133306pp480ra

D’Alessandro L., Miccadei E., Piacentini T., 2008. Morphotectonic study of the lower Sangro River valley (Abruzzi, Central Italy). Geomorphology 102(1): 145-158, DOI: 10.1016/j.geomorph.2007.06.019.

Dobija A., 1979. Związki korelacyjne między parametrami morfometrycznymi zlewni. Zeszyty Naukowe UJ, Prace Geograficzne 47: 99-108.

El Hamdouni R., Irigaray C., Fernandez T., Chacón J., Keller E.A., 2008. Assessment of relative active tectonics, southwest border of Sierra Nevada (southern Spain). Geomorphology 96(1-2): 150-173, DOI: 10.1016/j.geomorph.2007.08.004

Engstrom W.N., 1989. Morphometric analysis of mountain drainage basins in the Basin and Range Province, USA. Zeitschrift f. Geomorfphologie N.F. 33: 443-453.

Evans I.S., 1972. Chapter 2-General Geomorphometry, Derivatives of Altitude and Descriptive Statistics. W: R.J. Chorley (red.), Spatial Analysis in Geomorphology. Harper and Row Publishers, New York, USA: $17-90$

Evans I.S., 2004. Geomorphometry. W: A. Goudie (red.), Encyclopedia of Geomorphology. Routledge, London: 435-439.

Faghih A., Samani B., Kusky T., Khabazi S., Roshanak R., 2012. Geomorphologic assessment of relative tectonic activity in the Maharlou Lake Basin, Zagros Mountains of Iran. Geological Journal 47: 30-40. DOI: $10.1002 / \mathrm{gj} .1329$

Figueroa A.M., Knott J.R., 2010. Tectonic geomorphology of the southern Sierra Nevada Mountains (California): Evidence for uplift and basin formation. Geomorphology 123(1): 34-45, DOI: 10.1016/j. geomorph.2010.06.009.

García-Tortosa F.J., Alfaro P., Galindo-Zaldívar J., Gibert L., López-Garrido A.C., Sanz de Galdeano C., Ureña M., 2008. Geomorphologic evidence of the active Baza Fault (Betic Cordillera, South Spain). Geomorphology 97(3-4): 374-391, DOI: 10.1016/j.geomorph.2007.08.007.

Garrote J., Heydt G.G., Cox R.T., 2008. Multi-stream order analyses in basin asymmetry: A tool to discriminate the influence of neotectonics in fluvial landscape development (Madrid Basin, Central Spain). Geomorphology 102(1): 130-144, DOI: 10.1016/j.geomorph.2007.07.023.

Golts S., Rosenthal E., 1993. A morphotectonic map of the Northern Arava in Israel, derived from isobase lines. Geomorphology 7(4): 305-315, DOI: 10.1016/0169-555X(93)90060-F.

Grohmann C.H., 2004. Morphometric analysis in geographic information systems: applications of free software GRASS and R. Computers and Geosciences 30(9-10): 1055-1067, DOI: 10.1016/j.cageo.2004.08.002

Grohmann C.H., Riccomini C., Alves F.M., 2007. SRTM-based morphotectonic analysis of the Pocos de Caldas Alkaline Massif, Southeastern Brazil. Computers and Geosciences 33(1): 10-19, DOI: 10.1016/j.cageo.2006.05.002.

Harasimiuk M., 1980. Rzeźba strukturalna Wyżyny Lubelskiej i Roztocza. Rozprawy habilitacyjne. Wydział BiNoZ UMCS, Lublin.

Harkins N.W., Anastasio D.J., Pazzaglia F.J., 2005. Tectonic geomorphology of the Red Rock fault, insights into segmentation and landscape evolution of a developing range front normal fault. Journal of Structural Geology 27: 1925-1939. DOI: 10.1016/j.jsg.2005.07.005

Horton R.E., 1945. Erosional development of streams and their drainage basins; hydrophysical approach to quantitative morphology. Bulletin of the Geological Society of America 56: 275-370.

Jarosiński M., 2006. Recent tectonic stress field investigations in Poland: a state of the art. Geological Quarterly 50(3): 303-321.

Jaroszewski W., 1994. Neotektonika i ruchy współczesne. W: R. Dadlez, W. Jaroszewski, Tektonika. PWN, Warszawa: 423-485.

Jaroszewski W., Piątkowska A., 1988. O naturze niektórych lineamentów (na przykładzie Roztocza). Annales Societatis Geologorum Poloniae 58: 423-443.

Joshi M., Kothyari G.C., Ahluvalia A., Pant P.D., 2010. Neotectonic Evidences of Rejuvenation in Kaurik-Chango Fault Zone, Northwestern Himalaya. Journal of Geographic Information System 2: 169176. DOI: $10.4236 /$ jgis.2010.23024 
Keller E., 1986. Investigation of Active Tectonics: Use of Surficial Earth Processes. W: R.E. Wallace (red.), Active Tectonics studies in Geophysics. Nat. Acad. Press, Washington DC: 136-147.

Keller E.A., Pinter N., 1996. Active Tectonics, Earthquakes, Uplift and Landscape. Prentice-Hall, Upper Saddle River, New Jersey.

Keller E.A., Pinter N., 2002. Active Tectonics, Earthquakes, Uplift and Landscape. 2nd Ed. Prentice Hall Earth Sciences Series, USA.

Khavari R., Arian M., Ghorashi M. 2009. Neotectonics of the South Central Alborz Drainage Basin, in NW Tehran, N Iran. Journal of Applied Sciences 9(2-3): 4115-4126. DOI: 10.3923/jas.2009.4115.4126

Kosmowska-Suffczyńska D., 1986. Analiza kierunków dolin jako przejawu zjawisk neotektonicznych (na przykładzie obrzeżenia Gór Świętokrzyskich). I Sesja Sprawozd. Inst. Nauk Fizyczn. UW, Warszawa: 75-86.

Kouli M., Vallianatos F., Soupios P., Alexakis D., 2006. A GIS example of Morphometric analysis in tectonic structures of Western Crete, Greece. WSEAS Transactions on Environment and Development 9(2): 1163-1168.

Kurkowski S., 1993. Szczegółowa Mapa Geologiczna Polski 1:50 000, arkusz Krasnobród (894). Wydawnictwo Państw. Inst. Geol. (1996), Warszawa.

Liszkowski J., 1993. The effects of Pleistocene ice-sheet loading-deloading cycles on the bedrock structure of Poland. Folia Quaternaria 64: 7-23.

Luo W., 1998. Hypsometric analysis with a geographic information system. Computers and Geosciences 24(8): 815-821.

Malicki A., 1955. Prace Eugeniusza Romera z zakresu kartometrii i morfometrii. Czasopismo Geograficzne 26(1-2): 66-75.

Malinowski J., 1993. Warunki hydrogeologiczne Roztocza w świetle tektoniki. W: M. Harasimiuk, J. Krawczuk, J. Rzechowski (red.), Tektonika Roztocza i jej aspekty sedymentologiczne, hydrogeologiczne i geomorfologiczno-krajobrazowe. Wydawnictwo WWP, Lublin-Lwów: 109-117.

Mapa Podziału Hydrograficznego Polski wykonana przez Zakład Hydrografii i Morfologii Koryt Rzecznych Instytutu Meteorologii i Gospodarki Wodnej na zamówienie Ministra Środowiska i sfinansowana ze środków Narodowego Funduszu Ochrony Środowiska i Gospodarki Wodnej. Online - http://mapa.kzgw.gov.pl/.

Margielewski W., Jankowski L., 2011. Budowa geologiczna. W: M. Krąpiec, L. Jankowski, W. Margielewski, J. Buraczyński, P. Krąpiec, J. Urban, A. Wysocka, M. Danek, E. Szychowska-Krąpiec, M. Bolka, T. Brzezińska-Wójcik, Ł. Chabudziński, A. Wałkowska, „Geopark Kamienny Las na Roztoczu” koncepcja geoochrony wraz z wykonaniem dokumentacji i badań naukowych niezbędnych dla funkcjonowania tej formy ochrony. Akademia Górniczo-Hutnicza im. Stanisława Staszica w Krakowie, Wydział Geologii, Geofizyki i Ochrony Środowiska, Kraków.

Maruszczak H., 1980. Stratigraphy and chronology of the Vistulian loesses in Poland. Quaternary Studies in Poland 2: 57-76.

Maruszczak H., Świeca A., 2004. Charakterystyka geologiczna i geomorfologiczna. W: A. Świeca (red.), Przyrodnicze uwarunkowania dynamiki obiegu wody i natężenia transportu fluwialnego w zlewni górnego Wieprza. Wydawnictwo UMCS, Lublin: 23-32.

Melton M.A., 1958. Correlation structure of morphometric properties of drainage systems and their controlling agents. Journal of Geology 66: 442-460

Miliaresis G.Ch., 2001. Geomorphometric mapping of Zagros Ranges at regional scale. Computers and Geosciences 27(7): 775-786, DOI: 10.1016/S0098-3004(00)00168-0.

Miller V.C., 1953. Quantitative geomorphological study of drainage basin characteristics in Clinch Mountain area, Tennessee. ONR Technical Report 3, Project 271-030. Columbia Univ., New York.

Mumipour M., Nejad H.T., 2011. Tectonics Geomorphology Setting of Khayiz Anticline Derived from GIS Processing, Zagros Mountains, Iran. Asian Journal of Earth Sciences 4: 171-182.

Musiał T., 1987. Miocen Roztocza (Polska południowo-wschodnia). Biuletyn Geologiczny 31: 5-140.

Narkiewicz M., 2007. Development and inversion of Devonian and Carboniferous basins in the eastern part of the Variscan fore land (Poland). Geological Quarterly 51(3): 231-256.
Pareta K., Pareta U., 2011. Quantitative Morphometric Analysis of a Watershed of Yamuna Basin, India using ASTER (DEM) Data and GIS. International Journal of Geomatics and Geosciences 2(1): 248-269.

Pedrera A., Pérez-Peña J.V., Galindo-Zaldívar J., Azañón J.M., Azor A., 2009. Testing the sensitivity of geomorphic indices in areas of low-rate active folding (eastern Betic Cordillera, Spain). Geomorphology 105(3-4): 218-231, DOI: 10.1016/j.geomorph.2008.09.026.

Pérez-Peña J.V., Azanon J.M., Azor A., 2009. CalHypso: An ArcGIS extension to calculate hypsometric curves and their statistical moments, Applications to drainage basin analysis in SE Spain. Computers and Geosciences 35(6): 1214-1223, DOI: 10.1016/j.cageo.2008.06.006.

Pérez-Peña J.V., Azor A., Azañón J.M., Keller E.A., 2010. Active tectonics in the Sierra Nevada (Betic Cordillera, SE Spain): Insights from geomorphic indexes and drainage pattern analysis. Geomorphology 119(1-2): 74-87, DOI: 10.1016/j.geomorph.2010.02.020.

Pike R.J., 1995. Geomorphometry - progress, practice, and prospect. Zeitschrift für Geomorphologie Supplementband 101: 221-238.

Pike R.J., Evans I.S., Hengl T., 2008. Geomorphometry. A Brief Guide. W: T. Hengl, H.I. Reuter (red.), Geomorphometry: Concepts, Software, Applications. Development in Soils Science. Elsevier, 33: 3-30.

Popielski W., 1992. Szczegółowa Mapa Geologiczna Polski 1:50 000, arkusz Tereszpol (893). Wydawnictwo Państw. Inst. Geol. (1996), Warszawa.

Pożaryski W., 1974. Obszar świętokrzysko-lubelski. W: Budowa geologiczna Polski. IV. Tektonika. Cz. I. Wydawnictwa Geologiczne, Warszawa: 349-363.

Rockwell T.K., Keller E.A., Johnson D.L., 1985. Tectonic geomorphology of alluvial fans and mountain fronts near Ventura, Kalifornia. W: M. Morisawa, T.J. Hack (red.), Tectonic Geomorphology. State University of New York, Binghamton: 183-207.

Schumm S.A., 1954. Evolution of drainage systems and slopes in badlands at Perth Amboy, New Jersey. ONR Technical Report 8, Project 389-1042. Columbia University, New York

Shahzad F., Gloaguen R., 2011a. TecDEM: A MATLAB based toolbox for tectonic geomorphology. Pt. 2. Surface dynamics and basin analysis. Computers and Geosciences 37(2): 261-271, DOI: 10.1016/j. cageo.2010.06.009.

Shahzad F., Gloaguen R., 2011b. TecDEM: A MATLAB based toolbox for tectonic geomorphology. Pt. 1. Drainage network preprocessing and stream profile analysis. Computers and Geosciences 37(2): 250260, DOI: $10.1016 /$ j.cageo.2010.06.008.

Singh V.P., 1988. Hydrologic Systems. Vol. I. Rainfall-Runoff Modeling. Prentice Hall 07632, USA.

Smith K.G., 1950. Standards for grading texture of erosional topography. American Journal of Science 248: 655-668.

Snyder N.P., Whipple K.X., Tucker G.E., Merritts D.J., 2000. Landscape response to tectonic forcing: Digital elevation model analysis of stream profiles in the Mendocino triple junction region, northern California. Geological Society of America Bulletin 112: 1250-1263.

Superson J., 1989. Litologia i stratygrafia piaszczystych utworów stokowych Roztocza Tomaszowskiego. Annales UMCS B 38(1983): 109-134.

Superson J., 1996. Funkcjonowanie systemu fluwialnego wyżynnej części dorzecza Wieprza w zlodowaceniu Wisły. Rozprawy habilitacyjne. Wydz. BiNoZ UMCS, Lublin.

Strada L., 1931/1932. O najważniejszych zagadnieniach i potrzebach morfometrii. Polski Przegląd Kartograficzny 5: 213-234.

Strahler A.N., 1952. Hypsometric (area-altitude) analysis of erosional topography. Geological Society of America Bulletin 63: 1117-1142.

Strahler A.N., 1954. Statistical analysis in geomorphic research. Journal of Geology 62: 1-25.

Szumowski A., 1967. Rozwój głównych kierunków morfometrii. Czasopismo Geograficzne 38(1): 37-54.

Świdrowska J., Hakenberg M., Poluhtoyić B., Seghedi A., Viśnakov I., 2008. Evolution of the Mesozoic basins on the southwestern edge of the East European Craton (Poland, Ukraine, Moldavia, Romania). Studia Geologica Polonica 130(1): 3-130.

Troiani F., Della Seta M., 2008. The use of the Stream Length-Gradient index in morphotectonic analysis of small catchments: A case study from Central Italy. Geomorphology 102: 159-168, DOI: 10.1016/j. geomorph.2007.06.020. 
Tsodoulos I.M., Koukouvelas I.K., Pavlides S., 2008. Tectonic geomorphology of the easternmost extension of the Gulf of Corinth (Beotia, Central Greece). Tectonophysics 453(1-4): 211-232. DOI: $10.1016 / \mathrm{j}$. tecto.2007.06.015

Warowna J., 1993. Współczesna aktywność tektoniczna w strefie południowej krawędzi Wyżyny Lubelskiej. W: M. Harasimiuk, J. Krawczuk, J. Rzechowski (red.), Tektonika Roztocza i jej aspekty sedymentologiczne, hydrogeologiczne i geomorfologiczno-krajobrazowe. Wydawnictwo TWWP, Lublin-Lwów: 66-70.

Wilson J.P., Gallant J.C., 2000. Terrain Analysis: Principles and Applications. John Wiley and Sons Inc., New York.

Wobus C., Whipple K.X., Kirby E., Snyder N., Johnson J. i in., 2006. Tectonics from Topography: Procedures, Promise and Pitfalls. W: S.D. Willett, N. Hovius, M.T. Brandon, D.M. Fisher (red.), Tectonics, Climate and Landscape Evolution. GSA Special Paper 398, Geological Society of America, Boulder, CO.: 55-74.
Wyrzykowski T., 1987. A New determination of recent vertical movement of the earth's crust in Poland. Journal of Geodynamics 8: 171-178.

Zaborski B., 1931/1932. Analiza morfometryczna rzeźby terenu niżowego. Wiadomości Służby Geograficznej 3: 177-211.

Znosko J., 1979. Teisseyre-Tornquist tectonic zone: some interpretative implications of recent geological and geophysical investigations. Acta Geologica Polonica 29(4): 365-382.

Zuchiewicz W., 2010. Neotektonika Karpat i zapadliska przedkarpackiego. Wydawnictwa AGH, Kraków.

Żelichowski A.M., 1983. Mapa tektoniczna 1:300 000. Tab. 43. W: S. Kozłowski, A.M. Żelichowski (red.), Atlas geologiczno-surowcowy obszaru lubelskiego. Wydawnictwa Instytutu Geologicznego, Warszawa.

Żyszkowska W., 1978. Zastosowanie numerycznych modeli terenu do kartometrycznej analizy rzeźby. Acta Universitatis Wratislaviensis, Prace Instytutu Geografii 340, A. 